\title{
Nuclear dynamics and stress responses in Alzheimer's disease
}

\author{
Artemis latrou ${ }^{\dagger}$, Eric M. Clark ${ }^{\dagger}$ and Yanling Wang ${ }^{*}$ (D
}

\begin{abstract}
In response to extracellular and intracellular stressors, the nucleus and nuclear compartments undergo distinct molecular changes to maintain cell homeostasis. In the context of Alzheimer's disease, misfolded proteins and various cellular stressors lead to profound structural and molecular changes at the nucleus. This review summarizes recent research on nuclear alterations in $\mathrm{AD}$ development, from the nuclear envelope changes to chromatin and epigenetic regulation and then to common nuclear stress responses. Finally, we provide our thoughts on the importance of understanding cell-type-specific changes and identifying upstream causal events in AD pathogenesis and highlight novel sequencing and gene perturbation technologies to address those challenges.
\end{abstract}

Keywords: Nucleus, Alzheimer's disease, Chromatin, Gene regulations, Cell cycle deregulation

\section{Background}

The membrane-bound nucleus is one of the complex features that arose from prokaryotic to eukaryotic cells through evolution. It contains genetic materials and acts as the control center of the cell to control the synthesis of ribosomes and proteins. Under normal circumstances, the nucleus regulates gene expression to maintain cell homeostasis. In response to environmental and intracellular insults, cells relay the "stress signals" through various signaling pathways to the nucleus to defend cells against stress and restore homeostasis.

An emerging concept that unifies Alzheimer's disease (AD) and other neurodegenerative diseases is that chronic response to oxidative stress and misfolded proteins disrupts neuronal function, leading eventually to neurodegeneration. In $\mathrm{AD}$, cellular stress is often initiated by oxidative stress and further enhanced by neurotoxic amyloid-beta $(A \beta)$ oligomers and phosphorylated tau (p-tau), as well as the release of inflammatory mediators [1]. With the nucleus being a point of convergence

\footnotetext{
*Correspondence: Yanling_Wang@rush.edu

${ }^{+}$Artemis latrou and Eric M. Clark contributed equally to this work. Rush Alzheimer's Disease Center, Rush University Medical Center, 1750 W. Harrison St., Chicago, IL 60612, USA
}

for stress response, a better understanding of its structural, molecular and functional changes would highlight intracellular underpinnings of $\mathrm{AD}$ pathogenic processes.

Accumulated studies have shown that cellular insults induce profound changes to the nuclear structure, as well as the epigenome and transcriptome in AD brains [2]. Here we summarize the recent literature on these nuclear changes in animal models of $\mathrm{AD}$ and $\mathrm{AD}$ postmortem brain tissue. We first outline the nuclear structure changes from the nuclear envelope and nuclear pore complexes (NPCs) to the nucleolus, then elaborate on multiple layers of epigenetic regulation of gene expression. Furthermore, we discuss DNA damage response (DDR) and cell cycle deregulation in AD pathogenesis. Lastly, we provide our thoughts on refining the molecular signature of $\mathrm{AD}$ and identifying the causal genes for therapeutic intervention.

\section{Main text}

Nuclear envelope and nucleolus in AD Nuclear envelope in $A D$

The nuclear envelope is a highly dynamic structure, consisting of the nuclear lamina and a double membrane connected at specific points where the NPCs form [3]. 
The nuclear lamina forms a dense fibrillar network regulating important cellular events such as DNA replication, gene regulation, and signal transduction. Lamins, the major architectural proteins of the lamina, also serve as a scaffold to tether chromatin-protein complexes to the nuclear lamina, thereby sustaining genomic stability. Lamina-associated domains (LADs), the chromatin positioned close to the nuclear lamina, display typical heterochromatin features and are usually flanked by insulator protein CTCF-binding sites [4]. Increased lamin $\mathrm{A}$ and lamin $\mathrm{C}$ levels have been detected with the aggravation of $\mathrm{AD}$ pathology in postmortem hippocampus [5], whereas lamin $B$ levels are reduced in $A D$ frontal cortices (Fig. 1A) [6]. In the same study, lamin dysfunction in a tau-transgenic Drosophila melanogaster AD model led to heterochromatin relaxation (Fig. 1B), DNA damage, and neuronal degeneration [6]. Interestingly, pharmacologic and genetic inhibition of thioredoxin1, an antioxidant, enhanced caspase- 6 activity in serum-deprived SH-SY5Y neurons, which resulted in the degradation of lamin B1 and nuclear envelop invagination [7]. This study indicates that thioredoxin1 a key regulator for nuclear lamina integrity. Consistently, reduced thioredoxin 1 was detected in AD mouse brain, a finding also reported in AD postmortem brains [8].

The NPC is embedded in the nuclear envelope, containing more than 500 copies of 30 distinct nucleoporin proteins (Nups). NPCs mediate selective nucleocytoplasmic transport by forming a permeability barrier with the intrinsically disordered phenylalanine-glycine-rich Nups (FG-Nups) in the center and scaffold Nups in the periphery [9]. Nups also play an essential role in transcriptional regulation to determine cellular fate and identity of various cell types in the brain [10], likely through coordinating super-enhancers [11].

Multiple studies have shown that the NPC structure and nucleocytoplasmic transport are altered in AD. Initial evidence came from the immunolabeling of nucleoporins and NPC-associated proteins on postmortem hippocampal sections. This study demonstrated increased nuclear irregularity accompanying intracellular neurofibrillary tangles (NFTs) in AD hippocampal neurons [12]. They also observed abnormal perinuclear accumulation of nuclear transport factor 2 (NTF2), a critical NPC-associated protein, in scattered CA1 neurons in $\mathrm{AD}$ (Fig. 1C). Furthermore, importin $\alpha$, an essential protein of cytoplasmic-nuclear transport, was also found accumulated in human $\mathrm{AD}$ hippocampal CA1 neurons [13] (Fig. 1C). Lastly, various transcription factors, such as TDP-43 [14] and ATF2 [14], were found mislocalized to the cytoplasm of AD neurons (Fig. 1D). These studies indicate the dysfunction of nucleocytoplasmic transport in AD. A recent study provided further evidence that pathological tau directly interacts with components of the NPC, including Nup98, leading to accelerated tau aggregation in the cytoplasm and impaired nucleocytoplasmic transport [15] (Fig. 1E). As expected, reducing soluble p-tau and Nup98 can restore nucleocytoplasmic transport in rTg4510 mice [15]. Concordantly, Paonessa et al. showed that tau mutations resulted in its hyperphosphorylation and mislocalization from axons to cell bodies and dendrites in stem cellderived neurons, leading to nuclear membrane deformation and nucleocytoplasmic transport defect [14].

\section{Nucleolus in $A D$}

The nucleolus, consisting of ribosomal DNA (rDNA), ribosomal RNA (rRNA), and proteins, is the site for ribosome biogenesis [16]. The nucleolus is compartmentalized into the fibrillar center, the dense fibrillar center, and the granular component for pre-rRNA transcription, processing, and ribosomal ribonucleoprotein (RNP) assembly respectively [17, 18]. Ribosomal biogenesis requires $80 \%$ of the cellular energy; therefore, cellular metabolism can directly affect nucleolar activities.

Abnormal nucleoli morphology and function have been implicated in AD [19]. Using design-based stereology, Iacono et al. measured the volumes of neuronal cell bodies, nuclei, and nucleoli in postmortem cortex and hippocampus $[20,21]$. Interestingly, asymptomatic $A D$ demonstrated significant neuronal hypertrophy, especially profound nucleoli hypertrophy in CA1 neurons of the hippocampus, compared with mild cognitive impairment (MCI) cases with a similar load of AD pathology (Braak III-V) [20, 21], indicating a compensatory mechanism that prevents the disease progression into dementia. In contrast, definitive AD cases (Braak IV-VI) demonstrated significant atrophy of the neuronal cell bodies and nucleoli in the CA1 region [20, 21]. In line with this, Tagliavini et al. found significantly reduced nucleolar volume in the basal nucleus of Meynert, and the percentage volume reduction correlated with the percentage of cell loss in this region [20-22] (Fig. 1F).

Accumulated studies have indicated that rDNA transcription is regulated by different tau species. Immunogold labeling of human brain sections has shown that tau is expressed within the nucleolus and colocalizes with TIP5, a key player in heterochromatin stability, indicating a potential role for tau in rDNA transcriptional repression. Indeed, depleting tau in SH-SY5Y neuroblastoma cells decreases heterochromatin and DNA methylation, increasing rDNA transcription [23]. Federico et al. studied the cellular localization of the phosphorylated AT8 (Ser202/Thr205) and unphosphorylated Tau1 (Pro189/Gly207) epitopes of tau protein in the SK$\mathrm{N}-\mathrm{BE}$ cell line. They detected punctated staining for Tau1 in nucleoli of both proliferative and differentiated cells, whereas diffused AT8 staining in the entire 


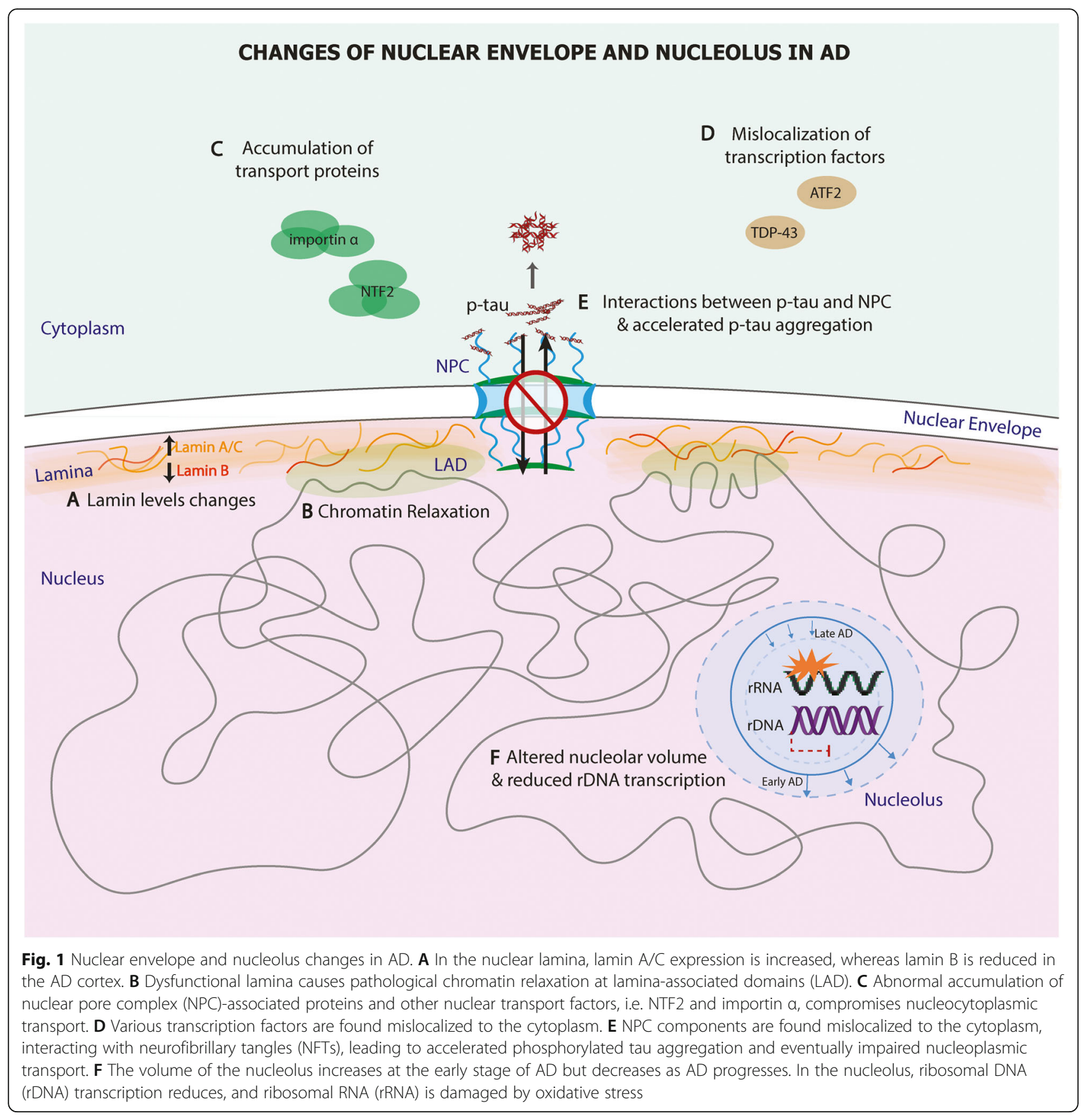

nucleolus of only differentiated cells [24]. Since the transcriptional activity is reduced in differentiated cells, this study also supports a possible role of rDNA silencing for p-tau during neuronal differentiation. It has been reported that $\mathrm{AD}$ patients have hypermethylated rDNA promoters and reduced rDNA transcription [25] (Fig. 1F). Whether this reduced rDNA transcription results from tau or p-tau is yet to be studied. Nevertheless, nuclear tau species may function differently under cellular stress. For example, glutamate-induced cellular stress triggered the redistribution of nucleolar tau, but not ptau [23]. Recently, Gil et al. conducted immunohistochemistry on postmortem brains at different ages and revealed that p-tau, AT100 (Thr212/Ser214), progressively increased in nuclei during aging and co-localized with the DAPI-positive heterochromatin [26]. Interestingly, AT100 was also detected in the nucleolus of pyramidal neurons in the CA1 region, with its highest expression in senescent cells in early AD stages and disappearing in more advanced stages [26] (Fig. 1F). In the 
same study pronounced AT100 expression in nucleoli at Braak stage I was in concordance with nucleolar hypertrophy while the absence of AT100 matched the drastic reduction in nucleolar volume observed in stages IV-V [26] (Fig. 1F).

In vitro culture and animal studies have also demonstrated the nucleolar responses to A $\beta$-related pathologies. Incubation of SH-SY5Y neuroblastoma cells with $A \beta$ oligomers for $24 \mathrm{~h}$ altered distribution of nucleolar tau, induced nucleolar stress and a reduction of rRNA synthesis and protein production [27]. Garcia-Esparcia et al. conducted a comparative study on nucleolar and ribosomal molecules in the cortex of postmortem $\mathrm{AD}$ individuals (Braak stage V-VI) versus APP/PS1 mice, and they detected significant but divergent protein and gene alternations related to the protein synthesis machinery from the nucleolus to the ribosome [28]. Furthermore, a recent study identified a long nucleolusspecific lncRNA (LoNA) that can serve as a sensor of neuronal activities, and its activity-dependent decrease leads to elevated rRNA levels, ribosome biosynthesis, and protein translation [29]. Notably, LoNA expression was elevated in the hippocampus of APP/PS1 mice, accompanied by reduced levels of rRNAs, and knockdown of LoNA restored rRNA expression and rescued cognitive and memory impairments in the same $A D$ mouse model [29].

Recent studies have attributed nucleolar stress response as a novel signaling pathway in early AD development (reviewed in [30]). For example, SHSY5Y cells treated with $\mathrm{A} \beta 42$ oligomers for $2 \mathrm{~h}$ showed oxidative stress and a significant reduction in UBF, a nucleolar transcription factor that drives the transcription of rDNA [30]. Furthermore, oxidative stress can directly affect rRNA, contributing to ribosome dysfunction by increasing the iron-binding capacity of rRNA. Consistent with this, ribosomes purified from the AD hippocampus contained significantly higher levels of RNase-sensitive iron and redox activity [31]. In addition, $\mathrm{AD}$ and MCI cortices demonstrated elevated rRNA oxidation and reduced rRNA level [32, 33] (Fig. 1D). Lastly, the application of DNA damage reagents or blocking rRNA synthesis reduced nucleolar rRNA transcription, leading to p53-dependent protracted neuronal degeneration in vitro [31,34]. Therefore, the nucleolus may serve as a critical stress-sensor and gatekeeper to maintain the cell homeostatic state, initiating neurodegenerative molecular changes upon cellular stress.

\section{Nuclear chromatin in AD}

\section{Histone modifications in $A D$}

Histone post-translational modifications (PTMs) are a significant contributor to the epigenetic regulation of gene expression. Histone methylation and histone acetylation are the two common but distinct forms of histone PTMs. Histone methylation, catalyzed by histone methyltransferases, occurs on specific $\mathrm{N}$-terminus lysines of histones $\mathrm{H} 3$ and $\mathrm{H} 4$ to either increase or repress transcription of the nearby genes [35]. Histone acetylation, executed by histone acetyltransferases (HATs), generally results in transcriptional activation; conversely, histone deacetylases (HDACs) reverse histone acetylation and suppress transcription.

Histone methylation changes linked to heterochromatin state have been implicated in AD but remain inconclusive. Frost et al. examined the H3K9me2, a heterochromatin mark for constitutive telomeric and pericentromeric heterochromatin along with the heterochromatin protein $1 \alpha(\mathrm{HP} 1 \alpha)$ in tau-induced neurodegeneration [36]. They found widespread loss of these heterochromatin marks and aberrant gene expression in tau transgenic Drosophila and mice, and in the human AD hippocampus (Braak stages V/VI). Leveraging public chromatin immunoprecipitation followed by sequencing (ChIP-seq) datasets from human AD brains, they also revealed a widespread transcriptional increase in genes silenced in controls due to heterochromatin state [36]. On the contrary, Zheng and others used similar experimental approaches but detected significant elevation of H3K9me2 in 5XFAD mouse model and the prefrontal cortex of postmortem human AD brains. Concomitantly, H3K9me2 at glutamate receptors was increased in the prefrontal cortex of aged 5XFAD mice; treating FAD mice with specific histone methyltransferase inhibitors, reversed histone hypermethylation, restored glutamate receptor expression and cognitive impairment [37]. Meanwhile, Lee and others discovered that H3K9me3mediated heterochromatin condensation was also elevated in sporadic $A D$ postmortem cortices (Braak stages V/VI). By combining H3K9me3 ChIP-seq and mRNAseq, they discovered that epigenomes highly occupied by H3K9me3 were inversely correlated with their mRNA expression levels in $\mathrm{AD}$, and the downregulated genes were mainly involved in synaptic function and neuronal differentiation [38].

Histone acetylation changes have also been implicated in $\mathrm{AD}$ pathogenesis (Fig. 2A). Early work from the Johnson group reported elevated expression of HDAC6 in human AD cortices and hippocampi [39]. Interestingly, they showed that HDAC6 interacted with tau, and inhibition of HDAC6 in HEK cells did not disrupt HDAC6-tau interaction but attenuated tau phosphorylation [39]. Tsai group conducted ChIP-PCR on the hippocampal CA1 tissue of the CK-p25 AD mouse model and revealed loss of H2BK5ac, H3K14ac, H4K5ac, and H4K12ac on neuroplasticity genes. They further experimentally validated that this epigenetic blockade was mediated by elevated HDAC2, which was also detected in 
the CA1 area of 5XFAD mice and in AD patients (Braak I-VI) [40]. The initial effort of using targeted proteomics to measure histone acetylation was made to measure H3K18/K23ac in a limited set of human samples and found a significant reduction of H3K18/K23ac levels in the $\mathrm{AD}$ temporal cortex [41]. A recent study demonstrated that astrocytic ApoE particles promote acetylation of $\mathrm{H} 3 \mathrm{~K} 9, \mathrm{H} 3 \mathrm{~K} 27, \mathrm{H} 4 \mathrm{~K} 5$, and $\mathrm{H} 4 \mathrm{~K} 12$ in cultured neurons, which subsequently enhanced transcription of neuronal immediate early genes (IEGs) that favor memory consolidation [42]. Indeed, ApoE knockout mice showed drastically reduced H3K27ac marks on the promoter regions of IEGs in response to a learning and memory training paradigm, and human ApoE4 targeted replacement (TR) mice demonstrated less enriched H3K27ac than ApoE3 TR mice, indicating that ApoE4 is less capable of promoting histone acetylation [42]. In line with those studies, HDAC inhibitors have shown promise as a therapeutic approach to combat the cognitive impairment associated with aging and neurodegenerative disease [43-45].

The application of ChIP-seq has enabled genome-wide analysis of acetylation patterns in postmortem AD brain tissue. In this regard, Nativio et al. conducted the first ChIP-seq for H4K16ac, a key modification related to aging and cellular senescence [46], on the lateral temporal lobe of 31 younger and elderly cognitively normal controls as well as AD patients. They found that H4K16ac peaks were predominantly increased with normal aging but lost in AD. Notably, altered H4K16ac peaks in the $\mathrm{AD}$ cortex were enriched for $\mathrm{AD}$-associated single nucleotide polymorphisms (SNPs) and expression quantitative trait loci (eQTL) [46]. Recently, the Mill group conducted ChIP-seq for H3K27ac, a robust mark of active enhancers and promoters, on the entorhinal cortex of 47 elderly individuals comprising of both $\mathrm{AD}$ cases (Braak VI) and controls. They identified thousands of differential peaks in $\mathrm{AD}$ brains associated with transcriptional alterations at nearby genes [47]. Consistent with the H4K16ac study, those H3K27ac differential peaks also represented a significant enrichment of $A D$ risk variants, including genetic regions involved in $A D$ neuropathology such as APP, PSEN1, PSEN2, and $M A P T$. With a sample size of 669 cases from the ROSMAP cohort, Klein et al. conducted ChIP-seq for H3K9ac, another histone mark for transcriptionally active open chromatin, in the dorsolateral prefrontal cortex of control and AD individuals. They found that tau protein burden, but not $A \beta$, coincided with widespread H3K9ac chromatin remodeling, and the majority of H3K9ac domains resided in the open chromatin region and were positively correlated with transcriptional changes in AD brains [48].

\section{DNA methylation in $A D$}

The most abundant and broadly studied DNA modification, 5-methylcytosine $(5 \mathrm{mC})$, is the addition of a methyl group at the cytosine in a $\mathrm{CpG}$ dinucleotide. Another stable epigenetic mark that is abundant in the brain is 5-hydroxymethylcytosine $(5 \mathrm{hmC})$, an oxidized form of the canonical $5 \mathrm{mC}$ catalyzed by teneleven translocation (TET) enzymes [49]. Although less prevalent, non- $\mathrm{CpG}(\mathrm{CpH})$ methylation also plays a critical role in many biological processes. It is widely accepted that increased methylation in promoter regions results in transcriptional repression, whereas hydroxymethylation of the same loci is associated with transcriptional activation [50].

Global methylation was initially assessed by immunohistochemistry but with inconclusive results. Mastroeni et al. first reported significantly reduced immunoreactivity of $5 \mathrm{mC}$ in tangle-bearing neurons of the temporal cortex of $\mathrm{AD}$ individuals [51, 52]. However, results from other studies using similar antibody-based methods showed either increased [53-55] or unaltered DNA methylation in the AD cortex [54]. With the advent of bead-based methylation arrays, extensive genome-wide profiling of DNA methylation was conducted in multiple brain regions of individuals with AD. Much like the immunohistochemistry results from global DNA methylation studies, the results have been inconclusive. Nevertheless, these methylation-wide association studies (MWAS) have revealed common methylation changes at a number of $\mathrm{AD}$ risk loci such as ANK1, BIN1, RHBDF2, HOXA3, CDH23, and RPL13 [56-61], providing relatively strong evidence that methylation of these genetic loci may be altered in AD. Recently, Zhang et al. conducted a meta-analysis of more than 1000 prefrontal cortex brain samples and identified 119 differentially methylated loci significantly associated with Braak stage progression; the most significant locus is the MAMSTR gene, a cofactor that regulates PU.1, a central gene hub in the AD [57]. Furthermore, Smith et al. combined the data of three cortical regions from six independent AD MWAS and identified 220 differentially methylated CpGs associated with the Braak stage, provided additional significant new differentially methylated loci, including PPT2/PRRT1, AGAP2, SLC44A2, and ADAM10 [62].

The majority of published AD MWAS studies are performed in bulk brain tissue that contains multiple cell types, including neurons, astrocytes, and microglia, all with potential distinct methylation patterns. Although corrections for cell-type composition through reference-based algorithms are applied, establishing cell-type-specific methylation changes is still challenging due to the different ratios between neurons and glia across brain regions. An exciting improvement in 
recent studies is to conduct methylation assays on enriched cell types isolated by fluorescence-activated cell sorting or laser-assisted microdissection [63-66]. Based on these studies, neurons and astrocytes each demonstrate thousands of differentially methylated CpGs associated with Braak stages but with only 5\% overlapping. Glia, especially microglia, primarily exhibit prominent CpG methylation in the ANK1 gene, whereas $\mathrm{CpG}$ methylation in neurons occurs in the $B I N 1, S E C 14 L 1, B R C A$, and $M C F 2 L$ genes [63-66]. Differentially methylated sites in AD neurons are primarily hypomethylated at $\mathrm{CpH}$ sites in the enhancer regions, associated with upregulated $\alpha_{\text {-secretase }} 1$ and increased plaque and tangle formation [67].

Association studies of $5 \mathrm{hmC}$ with $\mathrm{AD}$ neuropathology have been sprouting in the past couple of years. Coppieters et al. reported a global increase of both $5 \mathrm{mC}$ and $5 \mathrm{hmC}$ in neurons (but not glia) of AD frontal and temporal cortex using immunohistochemistry, correlated with AD pathology load [53]. While still lacking power and sample size for meta-analyses, some interesting findings have emerged. In postmortem AD brains, locusspecific changes in $5 \mathrm{hmC}$ have been associated with $\mathrm{AD}$ pathology [68]. By simultaneously profiling $5 \mathrm{mC}$ and $5 \mathrm{hmC}$ levels, Smith et al. discovered hypermethylation and hypohydroxymethylation at the ANK1 promoter in AD brains [69]. Recently, Lardenoije et al. revealed a novel differentially hydroxymethylated region in the CHRNB1 gene that encodes acetylcholine receptor beta subunit, crucial for cholinergic neurotransmission [60]. Moreover, Zhao et al. performed $5 \mathrm{hmC}$-capture sequencing and identified various differentially hydroxymethylated regions associated with plaques or neurofibrillary tangles. They also developed differential co-methylation network analysis and identified various modules with unique hub genes that drive AD pathology [68].

\section{Enhancers in $A D$}

Enhancers are gene regulatory elements where transcription factors bind to influence spatiotemporal gene expression programs [70]. Enhancers can undergo threedimensional interactions with promoters either locally or over large distances to regulate gene transcription [7173]. In addition, enhancers often show tissue- and celltype-specific activities [74-76], and neuronal enhancers are also regulated by cell activities [77].

SNPs in enhancer regions can influence the expression of genes and predispose individuals to $\mathrm{AD}$ [78]. Gjoneska et al. profiled seven chromatin states and transcriptional changes during the pathological progression of the hippocampus in the CK-p25 AD mouse model. They mapped orthologous genes in noncoding regions between mouse and human and found strong conservation of gene expression and epigenomic signatures. Notably, AD-associated SNPs were specifically enriched in increased-level enhancer orthologues with immune function, implicating immune processes in $\mathrm{AD}$ predisposition [79]. By integrating AD SNPs with publicly available data for enhancers that were annotated from 127 human tissues or cell types, a recent study revealed that about $96 \%$ of AD SNPs localize in non-coding regions, and $27 \%$ in enhancers [80]. Among those enhancer SNPs, 95\% reside in the same topological associated domains with their eQTL genes and genes associated with synaptic transmission, immune responses, and $\mathrm{A} \beta$ metabolism $[78,80,81]$.

Although the field just started to understand how enhancer variants affect gene expression in $\mathrm{AD}$, some exciting studies have emerged. For instance, some $A D$ enhancer variants regulate multiple eQTL genes by affecting the binding of CTCF or other cohesin complex subunits and chromatin looping [80]. The rs7364180 AD variant alters the expression of the transcription factor SREFB2 and then indirectly regulates $20 \mathrm{AD}$ risk genes through a cascade of transcriptional events [80]. The CLU intron variant rs2279590 affects $C L U$ expression and two other $\mathrm{AD}$ risk genes EPHX2 and PTK2B, by eliminating a transcription factor binding site for heat shock factor 1 (HSF1) [82]. Since most enhancers are unique to specific cell types, AD enhancer SNPs likely confer their functions in a cell-type-specific manner [83]. A powerful method to map active promotorenhancer interactome in specific cell types is to utilize proximity ligation-assisted ChIP-seq (PLAC-seq) in which proximity ligation preceded an enrichment for active promoters by H3K4me3 ChIP-seq. Using this approach, Nott et al. identified AD candidate causal variants in microglia-specific enhancers that were looped to corresponding active promoters. Indeed, deletion of a BIN1 microglia-specific enhancer harboring AD-risk variants ablated BIN1 expression in iPSC-derived microglia but not in neurons or astrocytes [81].

\section{Nuclear stress responses in $A D$ DNA damage response}

DNA lesions are sites of damage in the base-pairing or structure of DNA, classified as single-strand breaks (SSBs) and double-strand breaks (DSBs). They occur as either physiological or pathological cellular processes. Nevertheless, cells often initiate various mechanisms, termed DNA-damage response (DDR), to recognize and repair these incidents. Specifically, SSBs are usually recognized and corrected by the base excision repair (BER), and DSBs by either the error-prone non-homologous end-joining (NHEJ) or the homologous recombination $(\mathrm{HR})$. If the damage remains unrepaired, genome instability, cellular senescence, and cell death can subsequently occur $[84,85]$. 
In $\mathrm{AD}$, multiple brain cell types have been reported to harbor DNA damage due to oxidative stress and the inefficient DDR [85]. Evidence for DNA aberrations dates back to 1999, when DSBs and SSBs were detected in hippocampi of AD brains [86]. More recently, studies also showed increased levels of $\gamma \mathrm{H} 2 \mathrm{AX}$, a well-established marker of DSBs, in neurons and astrocytes of $\mathrm{AD}$ hippocampi and cortices [87, 88] (Fig. 2A). Interestingly, the elevation of $\gamma \mathrm{H} 2 \mathrm{AX}$ expression was detected in brains with $\mathrm{MCI}$ and preclinical $\mathrm{AD}$, suggesting an early contribution of DNA damage to AD pathophysiology [88]. As endogenous reactive oxygen species are the major source of DNA damage, cerebrospinal fluid (CSF) levels of DNA oxidation marker, the 8-OHdG has been proposed as a biomarker for AD early diagnosis in multiple studies [89].

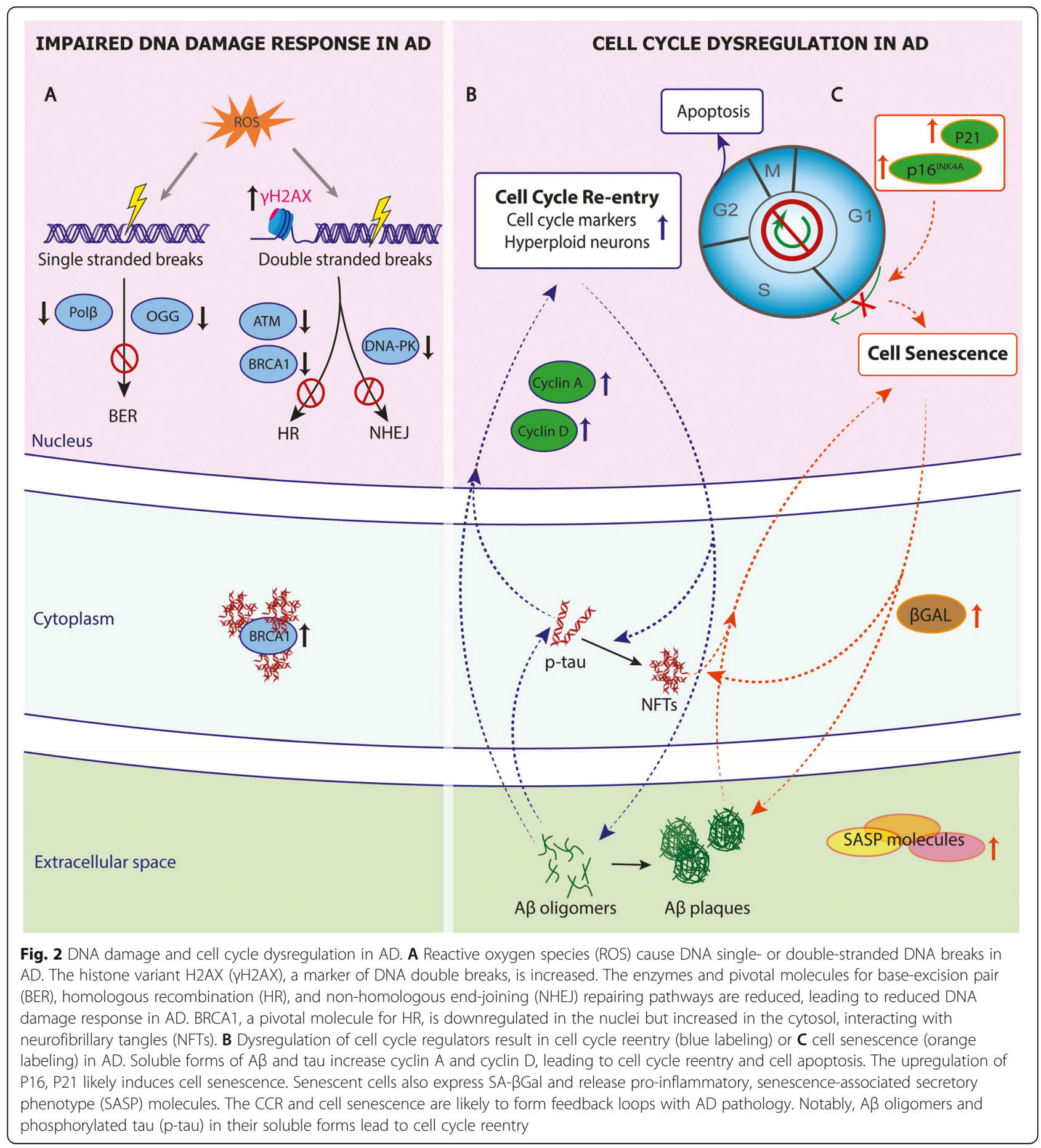


DNA BER pathway is the primary pathway to repair oxidized bases and subsequent DNA SSBs. In general, DNA glycosylase recognizes and removes the oxidized base, and then APE1 endonuclease, PNK kinase, DNA polymerase $\beta$ (Pol $\beta)$, and ligases III/I complete the repair. The major enzymes involved in BER have been found downregulated in $\mathrm{AD}$ [85] (Fig. 2A), and their changes correlate with the clinical manifestations and AD CSF biomarkers [90]. For instance, MCI and AD brains show decreased levels of $\operatorname{Pol} \beta$, a DNA polymerase primarily responsible for replacing single nucleotides during BER [91]. Interestingly, a recent study has shown that loss of $\mathrm{Pol} \beta$ is enough to drive cells into senescence [92], another potential mechanism contributing to AD pathophysiology (see cell senescence section). In the brains of both $\mathrm{AD}$ and MCI patients, there is a significant reduction of 8-oxoguanine DNA glycosylase (OGG), which excises oxidized DNA thereby preventing its accumulation [91]. Therefore, the profound changes of OGG, and Pol $\beta$ at the MCI stage suggest that the impaired BER responses could occur before overt $A D$ pathology.

Poly (ADP-ribose) polymerase 1 (PARP1) also contributes to BER by detecting an SSB and then signaling other DNA-repairing enzymes. In AD brains, elevated levels of poly (ADP-ribosylated) proteins, products synthesized by PARP1, have been detected [93]. Furthermore, DNA damage caused by $\mathrm{A} \beta$ can activate PARP- 1 in astrocytes, dopaminergic neurons, and hippocampal slices, which can further induce the p53 and reduce the Bcl-2 protein expression, leading to cell apoptosis [94, 95].

DSB repair pathways mediated by HR or NHEJ are also involved in AD (Fig. 2A). For instance, ATM and BRCA1, two pivotal molecules for $\mathrm{HR}$, have been found downregulated in AD brains and iPSC-derived neurons [96, 97]. A postmortem neuron-specific DNA methylome study revealed that the $B R C A 1$ promoter was hypomethylated in $\mathrm{AD}$, accompanied by a reduced BRCA1 expression in the nuclei but an increased expression in the cytosol, especially in tau-bearing insoluble aggregates [65]. Likewise, literature also suggests a compromised NHEJ-mediated repair pathway in AD. First, end-joining activity and protein levels of DNA-dependent protein kinase (DNA-PK), a kinase involved in repairing DSBs through NHEJ, were found reduced in AD cortices [98]. Moreover, the MRE11, a protein complex essential for NHEJ responses, is also decreased in AD cortical neurons [99].

\section{Cell cycle deregulation}

Cell cycle re-entry In eukaryotes, the cell cycle consists of four discrete phases: G1, S, G2, and M. Progression through these phases is regulated by cyclin-dependent kinases (CDKs) [100]. Neurons in the adult brain are terminally differentiated and generally thought to be incapable of re-entering the cell cycle. However, multiple studies suggest that neurons can re-enter the cell cycle from their quiescence G0 to G1 phase upon cellular stress and then continue into S, G2, or M phase [101106]. However, only a small number of those neurons eventually divide [106], and most of them undergo apoptosis [107]. Cell cycle re-entry (CCR) is likely mediated by multiple signaling pathways [104, 108-112].

Accumulated studies have detected cell cycle markers and regulatory proteins in postmortem brain tissue, supporting CCR present across multiple brain regions in all AD stages [113, 114] (Fig. 2B). As a result of CCR, hyperploid neurons are drastically increased at preclinical stages of $\mathrm{AD}$, indicating $\mathrm{CCR}$ is a potentially causal event in AD pathogenesis [115]. Indeed, SV40 large T antigen-induced CCR was reported to cause cortical deposition of $A \beta$ plaques and NFT pathology [116], in addition to neuronal degeneration [117]. Similarly, CCR induced by c-myc and ras oncogenes also increases ptau levels in cultured primary cortical neurons [118]. Furthermore, overexpressing denticle-less (DTL), a potent cell cycle regulator, induces $\mathrm{CCR}$ and subsequent tau hyperphosphorylation, $\mathrm{A} \beta$ production, and cognitive impairment in mice [119]. Consistently, many other studies also demonstrate that CDKs can drive the $\mathrm{A} \beta$ plaque formation [120-123] and tau phosphorylation [124, 125] (Fig. 2B).

On the other end, research evidence also shows that AD pathology triggers neuronal CCR. First, knock-in mice harboring human APP and PSEN1 show increased cyclin A and cyclin D1 in hippocampal and cortical neurons, leading to CCR and cell apoptosis [103, 126]. Moreover, oligomeric $\mathrm{A} \beta$ induces dose-dependent neuronal CCR, driving neurons into different cell cycle phases or apoptosis [111, 127]. This A $\beta$-induced CCR depends on tau phosphorylation by multiple protein kinases activated by $A \beta$, indicating soluble forms of $A \beta$ and tau are the essential elements for CCR [128]. Genetically perturbing cell-cycle progression in tau-expressing Drosophila models can reduce tau-induced neuronal apoptosis [129]. As such, A $\beta$ oligomers, phosphorylated tau, and CCR are likely to form feedback loops at the early stage of $\mathrm{AD}$ and ultimately lead to neuronal apoptosis (Fig. 2B).

Cell senescence Senescence is an irreversible cell cycle arrest due to the blockade to the $\mathrm{S}$ phase of the cycle. Cell senescence related to aging and neurodegeneration is often chronic. It includes replicative senescence [130], stress-induced premature senescence [131], and mitochondrial dysfunction-associated senescence [132]. Despite different categories, chronic cell senescence is generally characterized by a proinflammatory 
senescence-associated secretory phenotype (SASP), altered mitochondrial function, cellular metabolism, and DNA damage [133, 134].

Cell types in the central nervous system, including neurons, astrocytes, microglia, oligodendrocytes, have been reported to undergo cell senescence during aging. In $\mathrm{AD}, \mathrm{A} \beta$ plaques and NFTs, along with other cellular stressors, have been shown to induce DNA damage and alter chromatin structure, and subsequently leading to cell senescence [36, 135-143] (Fig. 2C). In postmortem AD brains, $A \beta$ plaques are commonly associated with oligodendrocyte precursor cells expressing senescent markers SA- $\beta$ Gal, p21 (CDKN1A), and p16 ${ }^{\mathrm{INK} 4}(\mathrm{CDKN} 2 \mathrm{~A})$ [144] (Fig. 2C). Moreover, laser-dissected neurons from AD brains also bear a transcriptomic profile characteristic of cell senescence, including proinflammatory cytokines and senescence-related upstream regulators [141] (Fig. 2C). Furthermore, senescent astrocytes marked by $\mathrm{p} 16^{\mathrm{INK} 4 \mathrm{~A}}$ and MMP-1 are increased with age and were more prominent in age-matched AD cortices [145]. Finally, microglia with dystrophic morphology and shorter telomeres also increases with age, but with a significantly higher number in AD brains [146-148]. Interestingly, a recent study indicates that increased myelin breakdown with age overwhelms microglial phagocytosis function, contributing to microglial senescence [149].

Mouse studies also provided evidence of senescent glia and neurons near $A \beta$ plaques or NFTs, but the cell types undergoing senescence varied among animal models [141, 144, 145, 150, 151]. However, regardless of cell types affected, ablation of senescent cells using either chemical or genetic approaches was protective against AD progression, indicating that cell senescence causally contributes to $\mathrm{AD}$ pathogenesis (Fig. 2C). For instance, selectively ablating senescent cells by senolytics in $\mathrm{AD}$ mouse models reduces SASP, neuroinflammation, plaque size, NFT burden, and alleviates cognitive declines [141, 144, 151]. Because senescent cells undergo profound chromatin and gene alterations [152-154], perturbing related factors have been shown to alter cell senescence and $\mathrm{AD}$ phenotype. For example, mice lacking one allele of Bmil, a core component of the polycomb repressive complex, shows relaxed heterochromatin, cellular senescence, amyloid plaque, and $\mathrm{p}$-tau formation; meanwhile, introducing mutant APP to Bmi1-deficient mice exacerbates amyloid and tau pathology [155].

The fate choice for stressed cells toward CCR or cell senescence is yet to be investigated in AD. Stressors such as oxidative stress, neuroinflammation, hypoxia, and DNA damage can affect nuclear integrity and regulation, inducing CCR or cell senescence [156-160]. Recent studies suggest that senescent cells result from insoluble NFT formation [141, 151], whereas CCR occurs before NFT and plaque formation [128], indicating the solubility of AD-related proteins as a potential determinant toward cell senescence or CCR. Thus, understanding the molecular underpinning of cell senescence and CCR will help us develop therapeutic strategies to mitigate cell cycle dysregulations in $\mathrm{AD}$ development.

\section{Conclusions}

This review discussed nuclear dynamics and nuclear stress response in $\mathrm{AD}$, focusing on nuclear architecture, chromatin modifications, and nuclear stress responses. These nuclear characteristics are dynamically regulated to collectively maintain cellular homeostasis. Therefore, abnormal changes reviewed here present the major nuclear perspectives of the AD pathological process. While this review focuses on nuclear mechanisms, multiple gene regulations outside the scope of this review have also shown emerging evidence of their implications in $\mathrm{AD}$, including transcriptional factors [161-163], RNA splicing [164-166], RNA editing [167], RNA binding proteins [168], microRNAs [169], nuclear non-coding RNAs (ncRNAs) [170], and enhancer RNAs (eRNAs) $[170,171]$. These gene regulators have been shown to shape gene expression and modulate chromatin architecture [170], but their precise mechanisms in AD remain to be explored [172, 173].

It is worth noting that molecular changes in $\mathrm{AD}$ often intertwine and occur concurrently to mediate $\mathrm{AD}$ progression. For instance, lamin dysfunction in a tautransgenic fly model of AD leads to heterochromatin relaxation and DDR [6]. DDR is also reported to trigger CCR and cell senescence [174-177] and reduces nucleolar rRNA transcription [31, 34]. Multi-omics studies from $\mathrm{AD}$ mouse models and postmortem brain tissue showed concordant changes among chromatin states, DNA accessibility, transcriptomics [48, 79], and widespread loss of $\mathrm{CpH}$ methylation at enhancers of $\mathrm{AD}$ neurons significantly converge on transcriptomic changes related to abnormal CCR, apoptotic and inflammatory pathways [67]. Furthermore, SNPs influencing epigenomic marks (xQTLs) overlap significantly with splicing QTLs in $A D$, and there is significant sharing of $x Q T L$ SNPs across the AD molecular phenotypes $[165,178]$. Repressor element 1-silencing transcription factor (REST), mediates active epigenetic repression of many genes that promote cell death and $\mathrm{AD}$ pathology, and at the same time, induces the expression of stress response genes [179].

How the different nuclear regulations occur coherently within the nucleus is still not clear. An emerging concept is that most nuclear regulatory processes occur through dynamic nuclear condensates that compartmentalize regulatory proteins and RNA molecules to proper 
genomic loci for coordinated nuclear regulations [180, 181]. The way the condensates are involved in disease progress is yet to be investigated. Notably, a recent study has revealed that the causal mutation of the methyl CpG binding protein 2 (MeCP2) disrupts its ability to form heterochromatin condensates, suggesting a novel mechanism for Rett syndrome [182].

One major challenge in $\mathrm{AD}$ research is understanding cell-type-specific molecular changes and their responses to intra- and extracellular pathology. We have seen exciting advances in applying single-cell biology and spatial transcriptomics in $\mathrm{AD}$ postmortem tissue and animal models in the past couple of years. These studies have provided invaluable information on cell-type-specific transcriptomic changes and revealed cell types implicated in early AD [183-186]. Furthermore, single-soma transcriptomics of tangle-bearing neurons directly maps tangle pathology to gene changes, proving an exciting approach to understanding pathology heterogeneity of single neurons in AD [186]. Lastly, a recent spatial transcriptomics study provides the first spatial map of transcriptional changes in the vicinity of $\mathrm{AD}$ pathogenic hallmarks and identifies plaques-induced gene networks in the early and late AD phases, respectively [183]. With these technologies rapidly evolving, we expect to see more impressive research systematically mapping multidimensional molecular changes in $\mathrm{AD}$ with unprecedented cellular, spatial and temporal resolution.

Another challenge is that epigenetic and transcriptomic changes in $\mathrm{AD}$ could result from genetic variants or/and pathological insults. Therefore, identifying the causal genetic variants and variant-driven transcriptional changes will allow us to construct the genetic circuitry of $\mathrm{AD}$ pathogenesis, thereby providing a better strategy for early $\mathrm{AD}$ intervention. By combining CRISPR gene editing with iPSC-based cell models, numerous studies have provided significant insights into the role of genetic variants in AD development [187-189]. Genetic perturbations can also be implemented in massively parallel genetic screens to interrogate gene functions in iPSCderived neural cell types [190]. Elegant genetic screening studies have been conducted in iPSC-derived neurons to identify causal genes for cell survival, oxidative stress, and lysosome dynamics [191, 192]. The advent of base editors [192, 193] and prime editing [194] technologies enable all possible single-base transition and transversion, providing a powerful platform to interrogate the function of genetic variants in $\mathrm{AD}$ development and establish the causal links from genetics to various intermediate molecular phenotypes.

Lastly, the dynamic nuclear structure alterations that contribute to $\mathrm{AD}$ can be investigated using experimental and computational approaches developed by the 4D nucleome project [195]. Visualizing chromatin contact sites with super-resolution microscopy [196] or sequencing $[197,198]$ has started to reveal exciting insight into chromatin structure changes in AD [199]. Implementation of these state-of-the-art technologies will help explain how the nuclear genome is maintained and regulated in $\mathrm{AD}$ progression, providing novel mechanistic insights into the molecular events and their dynamic progression.

\section{Abbreviations}

5hmC: 5-hydroxymethylcytosine; 5mC: 5-methylcytosine; Aß: Amyloid-beta; AD: Alzheimer's disease; BER: Base excision repair; CCR: Cell cycle re-entry;

CDKs: Cyclin-dependent kinases; ChIP-seq: Chromatin immunoprecipitation followed by sequencing; CSF: Cerebrospinal fluid; DDR: DNA-damage response; DNA-PK: DNA-dependent protein kinase; DSBs: Double-strand breaks; DTL: Denticle-less; eRNA: Enhancer RNA; eQTL: Expression quantitative trait loci; HATs: Histone acetyltransferases; HDACs: Histone deacetylases; HP1a: Heterochromatin protein 1a; HR: Homologous recombination; HSF1: Heat shock factor 1; LADs: Lamina-associated domains; IncRNA: Long noncoding RNA; LoNA: Long nucleolus-specific IncRNA; MAPT: Methyl CpG binding protein 2; MCl: Mild cognitive impairment; MWAS: Methylation-wide association studies; ncRNAs: Non-coding RNAs; NFTs: Neurofibrillary tangles; NHEJ: Non-homologous end-joining; NPC: Nuclear pore complex;

NTF2: Nuclear transport factor 2; Nups: Nucleoporin proteins; OGG: 8oxoguanine DNA glycosylase; PLAC-seq: Proximity ligation-assisted ChIP-seq; PoIB: DNA polymerase $\beta$; PPARY: Peroxisome proliferator-activated receptor $\gamma$; p-tau: Phosphorylated tau; PTMs: Post-translational modifications;

rDNA: Ribosomal DNA; REST: Repressor element 1-silencing transcription factor; RNP: Ribosomal ribonucleoprotein; rRNA: Ribosomal RNA;

SASP: Senescence-associated secretory phenotype; SNPs: Single-nucleotide polymorphisms; SSBs: Single-strand breaks; TET: Ten-eleven translocation

\section{Acknowledgements}

Not applicable.

\section{Authors' contributions \\ YW contributed to the conception, design and the structure of the manuscript. Al and EMC did the literature search and contributed equally to the writing of the manuscript. YW substantially revised and edited the manuscript. All authors read and approved the final manuscript.}

\section{Authors' information}

Al and EMC are Postdoctoral Scientists, and YW is an Associate Professor at Rush Alzheimer's Disease Center, Rush University Medical Center, Chicago, USA.

\section{Funding}

Not applicable.

Availability of data and materials Not applicable.

\section{Declarations}

Ethics approval and consent to participate Not applicable.

Consent for publication Not applicable.

Competing interests

The authors declare no competing interests. 
Received: 10 February 2021 Accepted: 1 September 2021 Published online: 17 September 2021

\section{References}

1. Kinney JW, Bemiller SM, Murtishaw AS, Leisgang AM, Salazar AM, Lamb BT. Inflammation as a central mechanism in Alzheimer's disease. Alzheimers Dement. 2018:4:575-90.

2. Bagyinszky E, Giau W, An SA. Transcriptomics in Alzheimer's disease: aspects and challenges. Int J Mol Sci. 2020;21(10):3517.

3. Romero-Bueno R, Ruiz PC, Artal-Sanz M, Askjaer P, Dobrzynska A. Nuclear organization in stress and aging. Cells. 2019;8(7):664.

4. van Steensel B, Belmont AS. Lamina-associated domains: links with chromosome architecture, heterochromatin, and gene repression. Cell. 2017; 169(5):780-91.

5. Méndez-López I, Blanco-Luquin I, Sánchez-Ruiz de Gordoa J, UrdánozCasado A, Roldán M, Acha B, et al. Hippocampal LMNA gene expression is increased in late-stage Alzheimer's disease. Int J Mol Sci. 2019;20(4):878.

6. Frost $B$, Bardai FH, Feany MB. Lamin dysfunction mediates neurodegeneration in tauopathies. Curr Biol. 2016;26(1):129-36.

7. Islam MI, Nagakannan P, Ogungbola O, Djordjevic J, Albensi BC, Eftekharpour E. Thioredoxin system as a gatekeeper in caspase-6 activation and nuclear lamina integrity: implications for Alzheimer's disease. Free Radic Biol Med. 2019;134:567-80.

8. Akterin S, Cowburn RF, Miranda-Vizuete A, Jiménez A, Bogdanovic N, Winblad B, et al. Involvement of glutaredoxin-1 and thioredoxin-1 in $\beta$ amyloid toxicity and Alzheimer's disease. Cell Death Differ. 2006;13(9):145465.

9. Kim SJ, Fernandez-Martinez J, Nudelman I, Shi Y, Zhang W, Raveh B, et al. Integrative structure and functional anatomy of a nuclear pore complex. Nature. 2018:555(7697):475-82.

10. D'Angelo MA, Gomez-Cavazos JS, Mei A, Lackner DH, Hetzer MW. A change in nuclear pore complex composition regulates cell differentiation. Dev Cell. 2012;22(2):446-58

11. Ibarra A, Benner C, Tyagi S, Cool J, Hetzer MW. Nucleoporin-mediated regulation of cell identity genes. Genes Dev. 2016;30(20):2253-8.

12. Sheffield LG, Miskiewicz HB, Tannenbaum LB, Mirra SS. Nuclear pore complex proteins in Alzheimer disease. J Neuropathol Exp Neurol. 2006; 65(1):45-54.

13. Lee $H G$, Ueda M, Miyamoto $Y$, Yoneda $Y$, Perry G, Smith MA, et al. Aberrant localization of importin alpha1 in hippocampal neurons in Alzheimer disease. Brain Res. 2006;1124(1):1-4.

14. Davidson Y, Amin H, Kelley T, Shi J, Tian J, Kumaran R, et al. TDP-43 in ubiquitinated inclusions in the inferior olives in frontotemporal lobar degeneration and in other neurodegenerative diseases: a degenerative process distinct from normal ageing. Acta Neuropathol. 2009;118(3):359-69.

15. Eftekharzadeh B, Daigle JG, Kapinos LE, Coyne A, Schiantarelli J, Carlomagno $Y$, et al. Tau protein disrupts nucleocytoplasmic transport in Alzheimer's disease. Neuron. 2018;99(5):925-40. e7.

16. Lempiäinen $H$, Shore D. Growth control and ribosome biogenesis. Curr Opin Cell Biol. 2009;21(6):855-63.

17. Feric M, Vaidya N, Harmon TS, Mitrea DM, Zhu L, Richardson TM, et al. Coexisting liquid phases underlie nucleolar subcompartments. Cell. 2016; 165(7):1686-97.

18. Kressler D, Hurt E, Baßler J. Driving ribosome assembly. Biochim Biophys Acta, Mol Cell Res. 2010;1803(6):673-83.

19. Hetman M, Pietrzak M. Emerging roles of the neuronal nucleolus. Trends Neurosci. 2012;35(5):305-14.

20. lacono D, Markesbery W, Gross M, Pletnikova O, Rudow G, Zandi P, et al. The Nun study: clinically silent $A D$, neuronal hypertrophy, and linguistic skills in early life. Neurology. 2009;73(9):665-73.

21. lacono D, O'Brien R, Resnick SM, Zonderman AB, Pletnikova O, Rudow G, et al. Neuronal hypertrophy in asymptomatic Alzheimer disease. $J$ Neuropathol Exp Neurol. 2008;67(6):578-89.

22. Tagliavini F, Pilleri G. Basal nucleus of Meynert: a neuropathological study in Alzheimer's disease, simple senile dementia, Pick's disease and Huntington's chorea. J Neurol Sci. 1983;62(1-3):243-60.

23. Maina MB, Bailey LJ, Wagih S, Biasetti L, Pollack SJ, Quinn JP, et al. The involvement of tau in nucleolar transcription and the stress response. Acta Neuropathol Commun. 2018;6(1):70.
24. Federico C, Gil L, Bruno F, D'Amico AG, D'Agata V, Saccone S. Phosphorylated nucleolar Tau protein is related to the neuronal in vitro differentiation. Gene. 2018;664:1-11.

25. Pietrzak M, Rempala G, Nelson PT, Zheng J-J, Hetman M. Epigenetic silencing of nucleolar rRNA genes in Alzheimer's disease. PLoS One. 2011; 6(7):e22585.

26. Gil L, Federico C, Pinedo F, Bruno F, Rebolledo AB, Montoya JJ, et al. Aging dependent effect of nuclear tau. Brain Res. 1677;2017:129-37.

27. Maina MB, Bailey LJ, Doherty AJ, Serpell LC. The involvement of A 442 and Tau in nucleolar and protein synthesis machinery dysfunction. Front Cell Neurosci. 2018;12:220

28. Garcia-Esparcia P, Sideris-Lampretsas G, Hernandez-Ortega K, Grau-Rivera O, Sklaviadis T, Gelpi E, et al. Altered mechanisms of protein synthesis in frontal cortex in Alzheimer disease and a mouse model. Am J Neurodegener Dis. 2017:6(2):15-25.

29. Li D, Zhang J, Wang M, Li X, Gong H, Tang H, et al. Activity dependent LoNA regulates translation by coordinating rRNA transcription and methylation. Nat Commun. 2018;9(1):1726.

30. Nyhus C, Pihl M, Hyttel P, Hall VJ. Evidence for nucleolar dysfunction in Alzheimer's disease. Nat Rev Neurosci. 2019;30(7):685-700.

31. Parlato R, Kreiner G, Erdmann G, Rieker C, Stotz S, Savenkova E, et al. Activation of an endogenous suicide response after perturbation of rRNA synthesis leads to neurodegeneration in mice. J Neurosci. 2008;28(48): 12759-64

32. Honda K, Smith MA, Zhu X, Baus D, Merrick WC, Tartakoff AM, et al. Ribosomal RNA in Alzheimer disease is oxidized by bound redox-active iron. J Biol Chem. 2005;280(22):20978-86.

33. Ding $Q$, Markesbery WR, Cecarini V, Keller JN. Decreased RNA, and increased RNA oxidation, in ribosomes from early Alzheimer's disease. Neurochem Res. 2006:31(5):705-10

34. Kalita K, Makonchuk D, Gomes C, Zheng JJ, Hetman M. Inhibition of nucleolar transcription as a trigger for neuronal apoptosis. J Neurochem. 2008;105(6):2286-99.

35. Santos $A L$, Lindner $A B$. Protein posttranslational modifications: roles in aging and age-related disease. Oxid Med Cell Longev. 2017;2017:5716409.

36. Frost $B$, Hemberg $M$, Lewis J, Feany MB. Tau promotes neurodegeneration through global chromatin relaxation. Nat Neurosci. 2014;17(3):357-66.

37. Zheng Y, Liu A, Wang ZJ, Cao Q, Wang W, Lin L, et al. Inhibition of EHMT1/2 rescues synaptic and cognitive functions for Alzheimer's disease. Brain. 2019; 142(3):787-807.

38. Lee MY, Lee J, Hyeon SJ, Cho H, Hwang YJ, Shin JY, et al. Epigenome signatures landscaped by histone H3K9me3 are associated with the synaptic dysfunction in Alzheimer's disease. Aging Cell. 2020;19:e13153.

39. Ding H, Dolan PJ, Johnson GV. Histone deacetylase 6 interacts with the microtubule-associated protein tau. J Neurochem. 2008;106(5):2119-30.

40. Gräff J, Rei D, Guan J-S, Wang W-Y, Seo J, Hennig KM, et al. An epigenetic blockade of cognitive functions in the neurodegenerating brain. Nature. 2012;483(7388):222-6.

41. Zhang K, Schrag M, Crofton A, Trivedi R, Vinters H, Kirsch W. Targeted proteomics for quantification of histone acetylation in a Izheimer's disease. Proteomics. 2012;12(8):1261-8

42. Li X, Zhang J, Li D, He C, He K, Xue T, et al. Astrocytic ApoE reprograms neuronal cholesterol metabolism and histone-acetylation-mediated memory. Neuron. 2021;109(6):957-70.e8.

43. Yang S-s, Zhang R, Wang G, Y-f Z. The development prospection of HDAC inhibitors as a potential therapeutic direction in Alzheimer's disease. Trans Neurodegener. 2017:6(1):1-6.

44. Sung YM, Lee T, Yoon H, DiBattista AM, Song JM, Sohn Y, et al. Mercaptoacetamide-based class II HDAC inhibitor lowers A $\beta$ levels and improves learning and memory in a mouse model of Alzheimer's disease. Exp Neurol. 2013;239:192-201.

45. Wagner F, Zhang Y-L, Fass D, Joseph N, Gale J, Weïwer M, et al. Kinetically selective inhibitors of histone deacetylase 2 (HDAC2) as cognition enhancers. Chem Sci. 2015;6(1):804-15.

46. Dang W, Steffen KK, Perry R, Dorsey JA, Johnson FB, Shilatifard A, et al. Histone $\mathrm{H} 4$ lysine 16 acetylation regulates cellular lifespan. Nature. 2009; 459(7248):802-7.

47. Marzi SJ, Leung SK, Ribarska T, Hannon E, Smith AR, Pishva E, et al. A histone acetylome-wide association study of Alzheimer's disease identifies diseaseassociated H3K27ac differences in the entorhinal cortex. Nat Neurosci. 2018. 21(11):1618-27. 
48. Klein H-U, McCabe C, Gjoneska E, Sullivan SE, Kaskow BJ, Tang A, et al. Epigenome-wide study uncovers large-scale changes in histone acetylation driven by tau pathology in aging and Alzheimer's human brains. Nat Neurosci. 2019;22(1):37-46.

49. Kriaucionis $\mathrm{S}$, Heintz N. The nuclear DNA base 5-hydroxymethylcytosine is present in Purkinje neurons and the brain. Science. 2009;324(5929):929-30.

50. Lardenoije R, latrou A, Kenis G, Kompotis K, Steinbusch HW, Mastroeni D, et al. The epigenetics of aging and neurodegeneration. Prog Neurobiol. 2015;131:21-64.

51. Mastroeni D, Grover A, Delvaux E, Whiteside C, Coleman PD, Rogers J. Epigenetic changes in Alzheimer's disease: decrements in DNA methylation. Neurobiol Aging. 2010;31(12):2025-37.

52. Mastroeni D, McKee A, Grover A, Rogers J, Coleman PD. Epigenetic differences in cortical neurons from a pair of monozygotic twins discordant for Alzheimer's disease. PLoS One. 2009:4(8):e6617.

53. Coppieters N, Dieriks BV, Lill C, Faull RL, Curtis MA, Dragunow M. Global changes in DNA methylation and hydroxymethylation in Alzheimer's disease human brain. Neurobiol Aging. 2014;35(6):1334-44.

54. Lashley T, Gami P, Valizadeh N, Li A, Revesz T, Balazs R. Alterations in global DNA methylation and hydroxymethylation are not detected in Alzheimer's disease. Neuropathol Appl Neurobiol. 2015;41(4):497-506.

55. Rao J, Keleshian V, Klein S, Rapoport S. Epigenetic modifications in frontal cortex from Alzheimer's disease and bipolar disorder patients. Transl Psychiatry. 2012;2(7):e132-e.

56. De Jager PL, Srivastava G, Lunnon K, Burgess J, Schalkwyk LC, Yu L, et al. Alzheimer's disease: early alterations in brain DNA methylation at ANK1, BIN1, RHBDF2 and other loci. Nat Neurosci. 2014;17(9):1156-63.

57. Yu L, Chibnik LB, Srivastava GP, Pochet N, Yang J, Xu J, et al. Association of Brain DNA methylation in SORL1, ABCA7, HLA-DRB5, SLC24A4, and BIN1 with pathological diagnosis of Alzheimer disease. JAMA Neurol. 2015;72(1): $15-24$.

58. Lunnon K, Smith R, Hannon E, De Jager PL, Srivastava G, Volta M, et al. Methylomic profiling implicates cortical deregulation of ANK1 in Alzheimer's disease. Nat Neurosci. 2014;17(9):1164-70.

59. Smith RG, Hannon E, De Jager PL, Chibnik L, Lott SJ, Condliffe D, et al. Elevated DNA methylation across a 48-kb region spanning the HOXA gene cluster is associated with Alzheimer's disease neuropathology. Alzheimers Dement. 2018:14(12):1580-8.

60. Lardenoije R, Roubroeks JA, Pishva E, Leber $M$, Wagner $H$, latrou $A$, et al. Alzheimer's disease-associated (hydroxy) methylomic changes in the brain and blood. Clin Epigenetics. 2019;11(1):164.

61. Watson CT, Roussos P, Garg P, Ho DJ, Azam N, Katsel PL, et al. Genomewide DNA methylation profiling in the superior temporal gyrus reveals epigenetic signatures associated with Alzheimer's disease. Genome Med. 2016;8(1):1-14.

62. Smith RG, Pishva E, Shireby G, Smith AR, Roubroeks JA, Hannon E, et al. A meta-analysis of epigenome-wide association studies in Alzheimer's disease highlights novel differentially methylated loci across cortex. Nat Commun. 2021:12(1):1-13.

63. Gasparoni G, Bultmann S, Lutsik P, Kraus TF, Sordon S, Vlcek J, et al. DNA methylation analysis on purified neurons and glia dissects age and Alzheimer's disease-specific changes in the human cortex. Epigenetics Chromatin. 2018;11(1):41

64. Hernández HG, Sandoval-Hernández AG, Garrido-Gil P, Labandeira-Garcia JL, Zelaya MV, Bayon GF, et al. Alzheimer's disease DNA methylome of pyramidal layers in frontal cortex: laser-assisted microdissection study. Epigenomics. 2018;10(11):1365-82.

65. Mano T, Nagata K, Nonaka T, Tarutani A, Imamura T, Hashimoto T, et al. Neuron-specific methylome analysis reveals epigenetic regulation and taurelated dysfunction of BRCA1 in Alzheimer's disease. Proc Natl Acad Sci. 2017;114(45):E9645-E54.

66. Mastroeni D, Sekar S, Nolz J, Delvaux E, Lunnon K, Mill J, et al. ANK1 is up-regulated in laser captured microglia in Alzheimer's brain; the importance of addressing cellular heterogeneity. PLoS One. 2017;12(7): e0177814.

67. Li P, Marshall L, Oh G, Jakubowski JL, Groot D, He Y, et al. Epigenetic dysregulation of enhancers in neurons is associated with Alzheimer's disease pathology and cognitive symptoms. Nat Commun. 2019:10(1):1-14.

68. Zhao J, Zhu Y, Yang J, Li L, Wu H, De Jager PL, et al. A genome-wide profiling of brain DNA hydroxymethylation in Alzheimer's disease. Alzheimers Dement. 2017;13(6):674-88.
69. Smith AR, Smith RG, Pishva E, Hannon E, Roubroeks JA, Burrage J, et al. Parallel profiling of DNA methylation and hydroxymethylation highlights neuropathology-associated epigenetic variation in Alzheimer's disease. Clin Epigenetics. 2019;11(1):1-13.

70. Ong C-T, Corces VG. Enhancer function: new insights into the regulation of tissue-specific gene expression. Nat Rev Genet. 2011;12(4):283-93.

71. Dowen JM, Fan ZP, Hnisz D, Ren G, Abraham BJ, Zhang LN, et al. Control of cell identity genes occurs in insulated neighborhoods in mammalian chromosomes. Cell. 2014;159(2):374-87.

72. Kagey MH, Newman JJ, Bilodeau S, Zhan Y, Orlando DA, van Berkum NL, et al. Mediator and cohesin connect gene expression and chromatin architecture. Nature. 2010;467(7314):430-5.

73. Schoenfelder S, Fraser P. Long-range enhancer-promoter contacts in gene expression control. Nat Rev Genet. 2019;20(8):437-55.

74. Blankvoort S, Witter MP, Noonan J, Cotney J, Kentros C. Marked diversity of unique cortical enhancers enables neuron-specific tools by enhancer-driven gene expression. Curr Biol. 2018;28(13):2103-14. e5.

75. Dong X, Liao Z, Gritsch D, Hadzhiev Y, Bai Y, Locascio JJ, et al. Enhancers active in dopamine neurons are a primary link between genetic variation and neuropsychiatric disease. Nat Neurosci. 2018;21(10):1482-92.

76. Fullard JF, Hauberg ME, Bendl J, Egervari G, Cirnaru M-D, Reach SM, et al. An atlas of chromatin accessibility in the adult human brain. Genome Res. 2018;28(8):1243-52

77. Gray JM, Kim T-K, West AE, Nord AS, Markenscoff-Papadimitriou E, Lomvardas S. Genomic views of transcriptional enhancers: essential determinants of cellular identity and activity-dependent responses in the CNS. J Neurosci. 2015;35(41):13819-26.

78. Carullo NV, Day JJ. Genomic enhancers in brain health and disease. Genes. 2019;10(1):43

79. Gjoneska E, Pfenning AR, Mathys H, Quon G, Kundaje A, Tsai L-H, et al. Conserved epigenomic signals in mice and humans reveal immune basis of Alzheimer's disease. Nature. 2015:518(7539):365-9.

80. Kikuchi M, Hara N, Hasegawa M, Miyashita A, Kuwano R, Ikeuchi T, et al. Enhancer variants associated with Alzheimer's disease affect gene expression via chromatin looping. BMC Med Genet. 2019;12(1):128.

81. Nott A, Holtman IR, Coufal NG, Schlachetzki JC, Yu M, Hu R, et al. Brain cell type-specific enhancer-promoter interactome maps and disease-risk association. Science. 2019:366(6469):1134-9.

82. Padhy B, Hayat B, Nanda GG, Mohanty PP, Alone DP. Pseudoexfoliation and Alzheimer's associated CLU risk variant, rs2279590, lies within an enhancer element and regulates CLU, EPHX2 and PTK2B gene expression. Hum Mol Genet. 2017;26(22):4519-29.

83. Heinz S, Romanoski CE, Benner C, Glass CK. The selection and function of cell type-specific enhancers. Nat Rev Mol Cell Biol. 2015;16(3):144-54.

84. Surova O, Zhivotovsky B. Various modes of cell death induced by DNA damage. Oncogene. 2013;32(33):3789-97.

85. Lin X, Kapoor A, Gu Y, Chow MJ, Peng J, Zhao K, et al. Contributions of DNA damage to Alzheimer's disease. Int J Mol Sci. 2020;21(5):1666.

86. Adamec E, Vonsattel JP, Nixon RA. DNA strand breaks in Alzheimer's disease. Brain Res. 1999;849(1-2):67-77.

87. Myung N-H, Zhu X, Kruman II, Castellani RJ, Petersen RB, Siedlak SL, et al. Evidence of DNA damage in Alzheimer disease: phosphorylation of histone H2AX in astrocytes. Age. 2008:30(4):209-15.

88. Shanbhag NM, Evans MD, Mao W, Nana AL, Seeley WW, Adame A, et al. Early neuronal accumulation of DNA double strand breaks in Alzheimer's disease. Acta Neuropathol Commun. 2019;7(1):77.

89. Peña-Bautista $C$, Tirle T, López-Noqueroles $M$, Vento M, Baquero M, CháferPericás C. Oxidative damage of DNA as early marker of Alzheimer's disease. Int J Mol Sci. 2019;20(24):6136.

90. Lillenes MS, Rabano A, Støen M, Riaz T, Misaghian D, Møllersen L, et al. Altered DNA base excision repair profile in brain tissue and blood in Alzheimer's disease. Mol Brain. 2016:9(1):61.

91. Weissman L, Jo D-G, Sørensen MM, de Souza-Pinto NC, Markesbery WR, Mattson MP, et al. Defective DNA base excision repair in brain from individuals with Alzheimer's disease and amnestic mild cognitive impairment. Nucleic Acids Res. 2007;35(16):5545-55.

92. Ahmed AA, Smoczer C, Pace B, Patterson D, Cress CD. Loss of DNA polymerase $\beta$ induces cellular senescence. Environ Mol Mutagen. 2018;59(7): $603-12$.

93. Love S, Barber R, Wilcock GK. Increased poly (ADP-ribosyl) ation of nuclear proteins in Alzheimer's disease. Brain. 1999;122(2):247-53. 
94. Strosznajder JB, Czapski GA, Adamczyk A, Strosznajder RP. Poly (ADP-ribose) polymerase-1 in amyloid beta toxicity and Alzheimer's disease. Mol Neurobiol. 2012;46(1):78-84.

95. Martire S, Fuso A, Rotili D, Tempera I, Giordano C, De Zottis I, et al. PARP-1 modulates amyloid beta peptide-induced neuronal damage. PLoS One. 2013:8(9):e72169-e.

96. Shen X, Chen J, Li J, Kofler J, Herrup K. Neurons in vulnerable regions of the Alzheimer's disease brain display reduced ATM signaling. eNeuro. 2016;3(1): ENEURO.0124-15.2016

97. Wezyk M, Szybinska A, Wojsiat J, Szczerba M, Day K, Ronnholm H, et al. Overactive BRCA1 affects presenilin 1 in induced pluripotent stem cellderived neurons in Alzheimer's disease. J Alzheimers Dis. 2018;62(1):175202.

98. Shackelford DA. DNA end joining activity is reduced in Alzheimer's disease. Neurobiol Aging. 2006;27(4):596-605.

99. Jacobsen E, Beach T, Shen Y, Li R, Chang Y. Deficiency of the Mre11 DNA repair complex in Alzheimer's disease brains. Mol Brain Res. 2004;128(1):1-7.

100. Barnum KJ, O'Connell MJ. Cell cycle regulation by checkpoints. Methods Mol Biol. 2014;1170:29-40.

101. Zhu W, Giangrande PH, Nevins JR. E2Fs link the control of G1/S and G2/M transcription. EMBO J. 2004;23(23):4615-26.

102. Yang Y, Geldmacher DS, Herrup K. DNA replication precedes neuronal cell death in Alzheimer's disease. J Neurosci. 2001;21(8):2661-8.

103. Malik B, Currais A, Andres A, Towlson C, Pitsi D, Nunes A, et al. Loss of neuronal cell cycle control as a mechanism of neurodegeneration in the presenilin-1 Alzheimer's disease brain. Cell Cycle. 2008;7(5):637-46.

104. Chao A-C, Chen C-H, Chang S-H, Huang C-T, Hwang W-C, Yang D-I. Id 1 and sonic hedgehog mediate cell cycle reentry and apoptosis induced by amyloid beta-peptide in post-mitotic cortical neurons. Mol Neurobiol. 2019; 56(1):465-89.

105. Vincent I, Jicha G, Rosado M, Dickson DW. Aberrant expression of mitotic cdc2/cyclin B1 kinase in degenerating neurons of Alzheimer's disease brain. J Neurosci. 1997;17(10):3588-98.

106. Walton CC, Zhang W, Patiño-Parrado I, Barrio-Alonso E, Garrido J-J, Frade JM. Primary neurons can enter M-phase. Sci Rep. 2019;9(1):1-15.

107. Copani A, Sortino MA, Nicoletti F, Bruno V, Ubertia D, Memo M. Activation of cell-cycle-associated proteins in neuronal death: a mandatory or dispensable path? Trends Neurosci. 2001;24(1):25-31.

108. Chao A-C, Chen C-H, Wu M-H, Hou B-Y, Yang D-I. Roles of Id1/HIF-1 and CDK5/HIF-1 in cell cycle reentry induced by amyloid-beta peptide in postmitotic cortical neuron. Biochim Biophys Acta, Mol Cell Res. 1867;2020(4): 118628.

109. Hung Y-H, Chang S-H, Huang C-T, Yin J-H, Hwang C-S, Yang L-Y, et al. Inhibitor of differentiation-1 and hypoxia-inducible factor-1 mediate sonic hedgehog induction by amyloid beta-peptide in rat cortical neurons. Mol Neurobiol. 2016;53(2):793-809.

110. Giovanni A, Wirtz-Brugger F, Keramaris E, Slack R, Park DS. Involvement of cell cycle elements, cyclin-dependent kinases, pRB, and E2F. DP, in Bamyloid-induced neuronal death. J Biol Chem. 1999:274(27):19011-6.

111. Majd S, Zarifkar A, Rastegar K, Takhshid MA. Different fibrillar Aß 1-42 concentrations induce adult hippocampal neurons to reenter various phases of the cell cycle. Brain Res. 2008;1218:224-9.

112. Lopes JP, Oliveira CR, Agostinho P. Cdk5 acts as a mediator of neuronal cell cycle re-entry triggered by amyloid- $\beta$ and prion peptides. Cell Cycle. 2009; 8(1):97-104.

113. Keeney JT, Swomley AM, Harris JL, Fiorini A, Mitov MI, Perluigi M, et al. Cell cycle proteins in brain in mild cognitive impairment: insights into progression to Alzheimer disease. Neurotox Res. 2012;22(3):220-30

114. Yang Y, Mufson EJ, Herrup K. Neuronal cell death is preceded by cell cycle events at all stages of Alzheimer's disease. J Neurosci. 2003;23(7): 2557-63.

115. Arendt T, Brückner MK, Mosch B, Lösche A. Selective cell death of hyperploid neurons in Alzheimer's disease. Am J Pathol. 2010;177(1):15-20.

116. Park KH, Hallows JL, Chakrabarty P, Davies P, Vincent I. Conditional neuronal simian virus $40 \mathrm{~T}$ antigen expression induces Alzheimer-like tau and amyloid pathology in mice. J Neurosci. 2007;27(11):2969-78.

117. Barrio-Alonso E, Hernández-Vivanco A, Walton CC, Perea G, Frade J. Cell cycle reentry triggers hyperploidization and synaptic dysfunction followed by delayed cell death in differentiated cortical neurons. Sci Rep. 2018;8(1):1-14
118. McShea A, Lee HG, Petersen RB, Casadesus G, Vincent I, Linford NJ, et al Neuronal cell cycle re-entry mediates Alzheimer disease-type changes. Biochim Biophys Acta, Mol Cell Res. 2007;1772(4):467-72.

119. Huang F, Wang M, Liu R, Wang J-Z, Schadt E, Haroutunian V, et al. CDT2controlled cell cycle reentry regulates the pathogenesis of Alzheimer's disease. Alzheimers Dement. 2019;15(2):217-31.

120. Ki I, Ando K, Takeda S, Satoh Y, Seki T, Itohara S, et al. Neuron-specific phosphorylation of Alzheimer's $\beta$-amyloid precursor protein by cyclindependent kinase 5. J Neurochem. 2000;75(3):1085-91.

121. Lee M-S, Kao S-C, Lemere CA, Xia W, Tseng H-C, Zhou Y, et al. APP processing is regulated by cytoplasmic phosphorylation. J Cell Biol. 2003; 163(1):83-95.

122. Liu F, Su Y, Li B, Zhou Y, Ryder J, Gonzalez-DeWhitt P, et al. Regulation of amyloid precursor protein (APP) phosphorylation and processing by p35/ Cdk5 and p25/Cdk5. FEBS Lett. 2003:547(1-3):193-6.

123. Suzuki T, Oishi M, Marshak D, Czernik A, Nairn A, Greengard P. Cell cycledependent regulation of the phosphorylation and metabolism of the Alzheimer amyloid precursor protein. EMBO J. 1994;13(5):1114-22

124. Kimura T, Ishiguro K, Hisanaga S-i. Physiological and pathological phosphorylation of tau by Cdk5. Front Mol Neurosci. 2014;7:65.

125. Patrick GN, Zukerberg L, Nikolic M, de La Monte S, Dikkes P, Tsai L-H. Conversion of p35 to p25 deregulates C $\mathrm{dk} 5$ activity and promotes neurodegeneration. Nature. 1999:402(6762):615-22.

126. Yang K, Hitomi M, Stacey DW. Variations in cyclin D1 levels through the cell cycle determine the proliferative fate of a cell. Cell Div. 2006;1:32.

127. Varvel NH, Bhaskar K, Patil AR, Pimplikar SW, Herrup K, Lamb BT. A oligomers induce neuronal cell cycle events in Alzheimer's disease. J Neurosci. 2008:28(43):10786-93.

128. Seward ME, Swanson E, Norambuena A, Reimann A, Cochran JN, Li R, et al. Amyloid- $\beta$ signals through tau to drive ectopic neuronal cell cycle re-entry in Alzheimer's disease. J Cell Sci. 2013;126(5):1278-86.

129. Khurana V, Lu Y, Steinhilb ML, Oldham S, Shulman JM, Feany MB. TORmediated cell-cycle activation causes neurodegeneration in a Drosophila tauopathy model. Curr Biol. 2006:16(3):230-41.

130. Harley $C B$, Futcher AB, Greider CW. Telomeres shorten during ageing of human fibroblasts. Nature. 1990;345(6274):458-60.

131. Toussaint O, Royer V, Salmon M, Remacle J. Stress-induced premature senescence and tissue ageing. Biochem Pharmacol. 2002:64(5-6):1007-9.

132. Kuilman T, Michaloglou C, Mooi WJ, Peeper DS. The essence of senescence. Genes Dev. 2010;24(22):2463-79.

133. Coppé J-P, Desprez P-Y, Krtolica A, Campisi J. The senescence-associated secretory phenotype: the dark side of tumor suppression. Annu Rev Pathol. 2010;5:99-118.

134. van Deursen JM. The role of senescent cells in ageing. Nature. 2014; 509(7501):439-46.

135. Sedelnikova OA, Horikawa I, Zimonjic DB, Popescu NC, Bonner WM, Barrett JC. Senescing human cells and ageing mice accumulate DNA lesions with unrepairable double-strand breaks. Nat Cell Biol. 2004;6(2):168-70.

136. Nakamura AJ, Chiang YJ, Hathcock KS, Horikawa I, Sedelnikova OA, Hodes $\mathrm{RJ}$, et al. Both telomeric and non-telomeric DNA damage are determinants of mammalian cellular senescence. Epigenetics Chromatin. 2008;1(1):6.

137. Rodier F, Coppé J-P, Patil CK, Hoeijmakers WA, Muñoz DP, Raza SR, et al. Persistent DNA damage signalling triggers senescence-associated inflammatory cytokine secretion. Nat Cell Biol. 2009;11(8):973-9.

138. Kang HT, Lee KB, Kim SY, Choi HR, Park SC. Autophagy impairment induces premature senescence in primary human fibroblasts. PLoS One. 2011;6(8): e23367.

139. Matos L, Gouveia A, Almeida H. Copper ability to induce premature senescence in human fibroblasts. Age. 2012;34(4):783-94.

140. Crowe EP, Tuzer F, Gregory BD, Donahue G, Gosai SJ, Cohen J, et al. Changes in the transcriptome of human astrocytes accompanying oxidative stress-induced senescence. Front Aging Neurosci. 2016:8:208.

141. Musi N, Valentine JM, Sickora KR, Baeuerle E, Thompson CS, Shen Q, et al. Tau protein aggregation is associated with cellular senescence in the brain. Aging Cell. 2018;17(6):e12840

142. Ishikawa S, Ishikawa F. Proteostasis failure and cellular senescence in longterm cultured postmitotic rat neurons. Aging Cell. 2020;19(1):e13071.

143. Von Zglinicki T. Oxidative stress shortens telomeres. Trends Biochem Sci. 2002;27(7):339-44

144. Zhang P, Kishimoto Y, Grammatikakis I, Gottimukkala K, Cutler RG, Zhang S, et al. Senolytic therapy alleviates $A \beta$-associated oligodendrocyte progenitor 
cell senescence and cognitive deficits in an Alzheimer's disease model. Nat Neurosci. 2019;22(5):719-28.

145. Bhat $R$, Crowe EP, Bitto A, Moh M, Katsetos CD, Garcia FU, et al. Astrocyte senescence as a component of Alzheimer's disease. PLoS One. 2012;7(9): e45069

146. Streit WJ, Braak H, Xue Q-S, Bechmann I. Dystrophic (senescent) rather than activated microglial cells are associated with tau pathology and likely precede neurodegeneration in Alzheimer's disease. Acta Neuropathol. 2009; 118(4):475-85

147. Flanary BE, Sammons NW, Nguyen C, Walker D, Streit WJ. Evidence that aging and amyloid promote microglial cell senescence. Rejuvenation Res. 2007;10(1):61-74.

148. Streit WJ, Mrak RE, Griffin WS. Microglia and neuroinflammation: a pathological perspective. J Neuroinflammation. 2004;1(1):14

149. Safaiyan S, Kannaiyan N, Snaidero N, Brioschi S, Biber K, Yona S, et al. Agerelated myelin degradation burdens the clearance function of microglia during aging. Nat Neurosci. 2016;19(8):995-8.

150. Amram S, Iram T, Lazdon E, Vassar R, Porath IB, Frenkel D. Astrocyte senescence in an Alzheimer's disease mouse model is mediated by TGF- $\beta 1$ and results in neurotoxicity. bioRxiv. 2019:700013.

151. Bussian TJ, Aziz A, Meyer CF, Swenson BL, van Deursen JM, Baker DJ. Clearance of senescent glial cells prevents tau-dependent pathology and cognitive decline. Nature. 2018;562(7728):578-82.

152. Sun L, Yu R, Dang W. Chromatin architectural changes during cellular senescence and aging. Genes. 2018;9(4):211.

153. Yang N, Sen P. The senescent cell epigenome. Aging (Albany NY). 2018; 10(11):3590.

154. Casella G, Munk R, Kim KM, Piao Y, De S, Abdelmohsen K, et al. Transcriptome signature of cellular senescence. Nucleic Acids Res. 2019; 47(14):7294-305.

155. El Hajjar J, Chatoo W, Hanna R, Nkanza P, Tétreault N, Tse YC, et al. Heterochromatic genome instability and neurodegeneration sharing similarities with Alzheimer's disease in old Bmi1+/- mice. Sci Rep. 2019;9(1): $1-16$.

156. Nguyen MD, Boudreau M, Kriz J, Couillard-Després S, Kaplan DR, Julien J-P. Cell cycle regulators in the neuronal death pathway of amyotrophic latera sclerosis caused by mutant superoxide dismutase 1. J Neurosci. 2003;23(6): 2131-40.

157. Zhu X, Rottkamp CA, Boux H, Takeda A, Perry G, Smith MA. Activation of p38 kinase links tau phosphorylation, oxidative stress, and cell cyclerelated events in Alzheimer disease. J Neuropathol Exp Neurol. 2000; 59(10):880-8

158. Kirouac L, Rajic AJ, Cribbs DH, Padmanabhan J. Activation of Ras-ERK signaling and GSK-3 by amyloid precursor protein and amyloid beta facilitates neurodegeneration in Alzheimer's disease. eNeuro. 2017:4(2): ENEURO.0149-16.2017

159. Kruman II, Wersto RP, Cardozo-Pelaez F, Smilenov L, Chan SL, Chrest FJ, et al. Cell cycle activation linked to neuronal cell death initiated by DNA damage. Neuron. 2004;41(4):549-61.

160. Gil L, Niño SA, Chi-Ahumada E, Rodríguez-Leyva I, Guerrero C, Rebolledo AB, et al. Perinuclear lamin A and nucleoplasmic lamin B2 characterize two types of hippocampal neurons through Alzheimer's disease progression. Int J Mol Sci. 2020;21(5):1841.

161. Canchi S, Raao B, Masliah D, Rosenthal SB, Sasik R, Fisch KM, et al. Integrating gene and protein expression reveals perturbed functional networks in Alzheimer's disease. Cell Rep. 2019;28(4):1103-16. e4.

162. Potashkin JA, Bottero V, Santiago JA, Quinn JP. Computational identification of key genes that may regulate gene expression reprogramming in Alzheimer's patients. PLoS One. 2019;14(9):e0222921.

163. Vargas DM, De Bastiani MA, Zimmer ER, Klamt F. Alzheimer's disease master regulators analysis: search for potential molecular targets and drug repositioning candidates. Alzheimers Res Ther. 2018;10(1):59.

164. Bai B, Hales CM, Chen P-C, Gozal Y, Dammer EB, Fritz JJ, et al. U1 small nuclear ribonucleoprotein complex and RNA splicing alterations in Alzheimer's disease. Proc Natl Acad Sci. 2013;110(41):16562-7.

165. Raj T, Li Yl, Wong G, Humphrey J, Wang M, Ramdhani S, et al. Integrative transcriptome analyses of the aging brain implicate altered splicing in Alzheimer's disease susceptibility. Nat Genet. 2018;50(11):1584-92.

166. Hsieh Y-C, Guo C, Yalamanchili HK, Abreha M, Al-Ouran R, Li Y, et al. Taumediated disruption of the spliceosome triggers cryptic RNA splicing and neurodegeneration in Alzheimer's disease. Cell Rep. 2019;29(2):301-16. e10.
167. Khermesh K, D'Erchia AM, Barak M, Annese A, Wachtel C, Levanon EY, et al. Reduced levels of protein recoding by A-to-I RNA editing in Alzheimer's disease. Rna. 2016;22(2):290-302.

168. Montalbano M, McAllen S, Puangmalai N, Sengupta U, Bhatt $N$, Johnson OD, et al. RNA-binding proteins Musashi and tau soluble aggregates initiate nuclear dysfunction. Nat Commun. 2020;11(1):1-16.

169. Wang M, Qin L, Tang B. MicroRNAs in Alzheimer's disease. Front Genet. 2019;10:153.

170. Sun Q, Hao Q, Prasanth KV. Nuclear long noncoding RNAs: key regulators of gene expression. Trends Genet. 2018;34(2):142-57.

171. Carullo NVN, Phillips lii RA, Simon RC, Soto SAR, Hinds JE, Salisbury AJ, et al. Enhancer RNAs predict enhancer-gene regulatory links and are critical for enhancer function in neuronal systems. Nucleic Acids Res. 2020;48:9550.

172. Faghihi MA, Modarresi F, Khalil AM, Wood DE, Sahagan BG, Morgan TE, et al Expression of a noncoding RNA is elevated in Alzheimer's disease and drives rapid feed-forward regulation of $\beta$-secretase. Nat Med. 2008;14(7): 723-30.

173. Faghihi MA, Zhang M, Huang J, Modarresi F, Van der Brug MP, Nalls MA, et al. Evidence for natural antisense transcript-mediated inhibition of microRNA function. Genome Biol. 2010;11(5):R56

174. Sola M, Magrin C, Pedrioli G, Pinton S, Salvadè A, Papin S, et al. Tau affects P53 function and cell fate during the DNA damage response. Commun Biol. 2020;3(1):1-15.

175. Martínez-Cué C, Rueda N. Cellular senescence in neurodegenerative diseases. Front Cell Neurosci. 2020;14:16.

176. Tokarz P, Kaarniranta K, Blasiak J. Role of the cell cycle re-initiation in DNA damage response of post-mitotic cells and its implication in the pathogenesis of neurodegenerative diseases. Rejuvenation Res. 2016;19(2): $131-9$.

177. Fielder E, Von Zglinicki T, Jurk D. The DNA damage response in neurons: die by apoptosis or survive in a senescence-like state? J Alzheimers Dis. 2017; 60(s1):S107-S31.

178. Ng B, White CC, Klein HU, Sieberts SK, McCabe C, Patrick E, et al. An xQTL map integrates the genetic architecture of the human brain's transcriptome and epigenome. Nat Neurosci. 2017;20(10):1418-26.

179. Lu T, Aron L, Zullo J, Pan Y, Kim H, Chen Y, et al. REST and stress resistance in ageing and Alzheimer's disease. Nature. 2014;507(7493):448-54.

180. Meyer-Nava S, Nieto-Caballero VE, Zurita M, Valadez-Graham V. Insights into HP1a-chromatin interactions. Cells. 2020;9(8):1866.

181. Sabari BR, Dall'Agnese A, Young RA. Biomolecular condensates in the nucleus. Trends Biochem Sci. 2020;45:961.

182. Li CH, Coffey EL, Dall'Agnese A, Hannett NM, Tang X, Henninger JE, et al. MeCP2 links heterochromatin condensates and neurodevelopmental disease. Nature. 2020;586(7829):440-4.

183. Chen W-T, Lu A, Craessaerts K, Pavie B, Frigerio CS, Corthout N, et al. Spatial transcriptomics and in situ sequencing to study Alzheimer's disease. Cell. 2020:182(4):976-91. e19.

184. Mathys H, Davila-Velderrain J, Peng Z, Gao F, Mohammadi S, Young JZ, et al. Single-cell transcriptomic analysis of Alzheimer's disease. Nature. 2019; 570(7761):332-7

185. Johnson TS, Xiang S, Helm BR, Abrams ZB, Neidecker P, Machiraju R, et al. Spatial cell type composition in normal and Alzheimers human brains is revealed using integrated mouse and human single cell RNA sequencing. Sci Rep. 2020;10(1):1-14.

186. Otero-Garcia M, Xue Y-Q, Shakouri T, Deng Y, Morabito S, Allison T, et al. Single-soma transcriptomics of tangle-bearing neurons in Alzheimer's disease reveals the signatures of tau-associated synaptic dysfunction. BioRxiv. 2020:2020.05.11.088591.

187. Lin Y-T, Seo J, Gao F, Feldman HM, Wen H-L, Penney J, et al. APOE4 causes widespread molecular and cellular alterations associated with Alzheimer's disease phenotypes in human iPSC-derived brain cell types. Neuron. 2018; 98(6):1141-54 e7.

188. Zhao J, Fu Y, Yamazaki Y, Ren Y, Davis MD, Liu C-C, et al. APOE4 exacerbates synapse loss and neurodegeneration in Alzheimer's disease patient iPSCderived cerebral organoids. Nat Commun. 2020;11(1):1-14.

189. Martins S, Müller-Schiffmann A, Erichsen L, Bohndorf M, Wruck W, Sleegers $K$, et al. IPSC-derived neuronal cultures carrying the Alzheimer's disease associated TREM2 R47H variant enables the construction of an Aß-induced gene regulatory network. Int J Mol Sci. 2020;21(12):4516.

190. Kampmann M. CRISPR-based functional genomics for neurological disease. Nat Rev Neurol. 2020;16(9):465-80. 
191. Tian R, Gachechiladze MA, Ludwig CH, Laurie MT, Hong JY, Nathaniel D, et al. CRISPR interference-based platform for multimodal genetic screens in human iPSC-derived neurons. Neuron. 2019;104(2):239-55. e12.

192. Tian R, Abarientos A, Hong J, Hashemi SH, Yan R, Dräger N, et al. Genomewide CRISPRi/a screens in human neurons link lysosomal failure to ferroptosis. Nat Neurosci. 2021;24(7):1020-34.

193. Gaudelli NM, Komor AC, Rees HA, Packer MS, Badran AH, Bryson DI, et al. Programmable base editing of a $\cdot T$ to $\mathrm{G} \cdot \mathrm{C}$ in genomic DNA without DNA cleavage. Nature. 2017;551(7681):464-71.

194. Anzalone AV, Randolph PB, Davis JR, Sousa AA, Koblan LW, Levy JM, et al. Search-and-replace genome editing without double-strand breaks or donor DNA. Nature. 2019;576(7785):149-57.

195. Dekker J, Belmont AS, Guttman M, Leshyk VO, Lis JT, Lomvardas S, et al. The 4D nucleome project. Nature. 2017;549(7671):219-26.

196. Boettiger A, Murphy S. Advances in chromatin imaging at kilobase-scale resolution. Trends Genet. 2020;36(4):273-87.

197. Tang Z, Luo OJ, Li X, Zheng M, Zhu JJ, Szalaj P, et al. CTCF-mediated human 3D genome architecture reveals chromatin topology for transcription. Cell. 2015;163(7):1611-27.

198. Lieberman-Aiden E, van Berkum NL, Williams L, Imakaev M, Ragoczy T, Telling $A$, et al. Comprehensive mapping of long-range interactions reveals folding principles of the human genome. Science. 2009:326(5950):289-93.

199. Winick-Ng W, Rylett RJ. Into the fourth dimension: dysregulation of genome architecture in aging and Alzheimer's disease. Front Mol Neurosci. 2018;11:60.

\section{Publisher's Note}

Springer Nature remains neutral with regard to jurisdictional claims in published maps and institutional affiliations.

Ready to submit your research? Choose BMC and benefit from:

- fast, convenient online submission

- thorough peer review by experienced researchers in your field

- rapid publication on acceptance

- support for research data, including large and complex data types

- gold Open Access which fosters wider collaboration and increased citations

- maximum visibility for your research: over $100 \mathrm{M}$ website views per year

At $\mathrm{BMC}$, research is always in progress.

Learn more biomedcentral.com/submissions 